\title{
Customer Relationship Management Practices and Customer Retention at Ghana Commercial Bank (GCB) in Tamale: Mediating Role of Customer Satisfaction
}

\author{
Eric Gonu ${ }^{1 *}$, Mary Konadu ${ }^{2}$ and Mary Asare-Larbi ${ }^{3}$ \\ 1. Department of Marketing and Supply Chain Management, University of Cape Coast, Ghana \\ 2. GCB Bank PLC, Tamale, Ghana \\ 3. Department of Marketing and Corporate Strategic Management, University for Development Studies, Tamale, \\ Ghana \\ *Corresponding author: eric.gonu@ucc.edu.gh
}

\begin{abstract}
With the recent increase in bank closures, attracting new customers and developing strong customer relationships in Ghana's financial sector has become difficult. As a result, customer retention in banking has become critical for fund mobilization and license maintenance. The study sought to investigate the effect of CRM practices and customer satisfaction on customer retention at GCB bank, Tamale. The quantitative research approach and the explanatory design were employed due to the purpose of the study. Structured questionnaire was used to gather data from all the 367 customers of GCB bank in Tamale. The data obtained were processed using Statistical Package for Social Sciences (SPSS) version 25 and analyzed using descriptive and inferential tools. The purpose of this study was to investigate and establish a comprehensive framework to identify customer relationship management practices on customer retention through the mediating role of customer satisfaction. The study discovered a significant positive relationship between customer relationship management practices and customer retention, as well as customer satisfaction playing a mediating role in this relationship. As a result, Ghanaian banks are implored to implement effective customer relationship marketing strategies in order to retain their customers.
\end{abstract}

Keywords:Customer Relationship Management (CRM) Practices, Customer Retention, Customer Focus, Knowledge Management, Technology-based CRM, Customer Satisfaction.

DOI: $10.7176 / \mathrm{JMCR} / 85-02$

Publication date: February $28^{\text {th }} 2022$

\section{Introduction}

Banks acts an intermediary role in socioeconomic growth throughout the globe by mobilizing funds from surplus sectors and providing new products (including credit) and services to entrepreneurs and deficit sectors for productive and sustainable economic activities (Daly \& Frikha, 2016; Saksonova \& Koeda, 2017; Türsoy, 2018). Other researchers have claimed that banks are crucial in improving industrialisation and establishing new economic paths. In many developing nations, like Ghana, the financial industry plays a critical role in economic development and poverty alleviation (Beck \& Demirguc-Kunt, 2009).

Banks, on the other hand, have been in a constant battle to grow profits and satisfy minimum capital requirements in recent years. The Bank of Ghana $(\mathrm{BoG})$, for example, published a guideline on new minimum criteria for regulating banks in 2018. As a result of this new development, banks are now competing fiercely for clients. In order to mobilize adequate funds and maintain their licenses, banks must attract new clients and develop strong customer connections. Customers are seen as stepping stones and the most essential intangible assets for any company, according to studies (Tauni et al., 2014; Khadka \& Maharjan, 2017). Customers are the primary reason for an organization's survival (Gittell, 2002; Peltier et al., 2009), and they should be appreciated and handled well accordingly (Gupta \& Lehmann, 2003). Many researchers (Tauni et al., 2014; Tseng, 2016) have stated that the most essential method for companies to retain greater profit and become highly competitive is to establish and manage effective customer relations.

Owing to its beneficial impact on customer satisfaction and company success, the idea of customer relationship management (CRM) practices have been adopted by companies all over the globe after Berry's (1983) work on relationship marketing (Kebede \& Tegegne, 2018). CRM is a complete strategy and process for recruiting, keeping, and collaborating with chosen customers in order to provide better value for both the business and the customer (Parvatiyar \& Sheth, 2001). CRM techniques range from acquiring customers to providing excellent service and retaining them (Grönroos, 2004). Customer retention is defined by Kebede and Tegegne (2018) as a company's or organization's efforts and measures to minimize customer defections and maintain customer loyalty. Customer retention programs are designed to assist businesses in retaining as many customers as possible, usually via customer loyalty and brand loyalty efforts (Kebede \& Tegegne, 2018). Customer retention is also a means of ensuring that a product's consumers do not patronize rivals or competing 
businesses. Customer retention, according to Molapo and Mukwada (2011), is one of the most important elements affecting the success and continuation of companies. CRM has a major impact on customer retention in the banking sector, both from the viewpoint of management and customers (Kebede \& Tegegne, 2018).

Despite the many advantages of CRM implementation, poor implementation of CRM practices remains a problem in many developing nations' banks. CRM practice, especially in the banking sector, faces a number of obstacles (Oogarah-Hanuman et al., 2011). Customers of various banks in Nigeria often complain about lengthy queue, a lack of tellers at the counters, improper conduct by certain bank staff, and inadequate knowledge management (Ogburu \& Usman, 2012). Poor implementation of CRM has a detrimental impact on banks' ability to retain customers (Rouholamini \& Venkatesh, 2011). The banking industry, according to Mishra et al. (2011), has tremendous difficulties in recruiting new customers and retaining old customers. Oogarah-Hanuman (2011) further emphasizes that it is getting more difficult for banks to establish and maintain solid and long-term connections with customers in recent years. This necessitates banks providing a broad customer base with distinct products and high-quality services (Lakhani \& Smith, 2007).

It is against this backdrop of literature that this research seek to shed light on CRM practices at the commercial banking sector in Ghana, particularly in the Tamale Metropolis, and its effect on customer retention. The research will further investigate how the role of customer satisfaction can influence customer retention. The outcome of the research will offer a more accurate and scientific method for assessing an organization's satisfaction and retention rates of its customer base. The research objectives of the study are as follows; assess the effect of CRM practices at GCB on customer retention and examine the mediating effect of customer satisfaction on the relationship between CRM practices and customer retention.

\section{Literature Review}

Customer relationship management (CRM) is the practice of meticulously recording individual customers and all points of contact with them in order to increase retention (Kotler \& Keller, 2016). The utilization of CRM practices can positively impact customer retention, which have a strong link to it. Other factors that affect customer retention include business process structure, current technology, and knowledge management (Amir, et al., 2014). CRM practices are inextricably linked to customer retention, and they are becoming increasingly important in today's business climate. As such, employee behavior has a big impact on customer satisfaction, so the CRM elements of interaction management, relationship development, customer service, and employee conduct are all important (Long,et al., 2013).Customer satisfaction and retention are linked in CRM strategies, and a high level of customer satisfaction leads to customer retention (Shvydenko, 2011). Bashir (2017) further adds customer retention and CRM practices have a strong link (Bashir, 2017). Kalakota (2009), concludes that the goal of CRM practices is to improve customer management, enhance company profitability, and promote the process of constant sales to customers.

Typically, customer satisfaction is very important in establishing and improving customer retention and increasing profitability, according to Ganiyu (2017), however it is not always adequate in all situations. Consumers who have had positive experiences are more likely to make repeat purchases and become regular users of a particular product or service brand than customers who have had negative experiences (Pleshko and Heiens, 2015). According to Narteh and Kuada (2014), customer satisfaction in Ghana is determined by the relational, fundamental, and tangible dimensions of retail banking services. Customer satisfaction was shown to be a significant predictor or antecedent for consumers' tendency or desire to maintain their banking and patronage, (Tweneboah-Koduah and Farley, 2015). The findings from Tweneboah-Koduah and Farley (2015), also showed that, the capability of banks to guarantee service quality was also a vital determinant of customer satisfaction

Furthermore, customer retention has become essential to the financial success and sustainability of many businesses (Smith and Wright, 2004). Customer retention is defined by Kebede and Tegegne (2018) as a company's efforts and measures to minimize customer defections and retain loyal customers. They go on to say that the objective of customer retention programs is to assist businesses retain as many customers as possible, which they do through promoting customer loyalty and brand loyalty (Kebede \& Tegegne, 2018).

According to many studies, customer retention helps businesses by increasing long-term profitability, reducing marketing costs, increasing referrals, and increasing customer growth (Anubav, 2010; Reichheld, 2006; Kent and Löfmarck, 2000). An empirical study by Hasanat et al. (2019) posits that customer satisfaction and retention may be accomplished through customer engagement process. According to Bashir (2017), satisfaction of customers mediates the link between CRM and customer retention in the banking industry, and customer happiness and fulfillment may be obtained through effective CRM practice. Gayathry (2016) stated that banks may completely accomplish CRM maintenance if they make efforts to improve customer engagement.

Another key variable of CRM is Knowledge Management. Customer knowledge management, according to Chua and Banerjee (2013), is an efficient tool for evaluating customer expectations, behavior, and preferences. Duwailah and Hashem (2019) verified that the utilization of customer knowledge management enables 
businesses to increase its profitability through CRM practices. According to San and Hardjono (2017), customer retention is significantly linked with variables such as customer orientation and knowledge management,

Moreover, other researchers Radaideh and Al-Talafih (2017) and Ramaj (2015) indicated clearly that technology-based CRM also improves satisfaction of customers. Through their study, Abbas et al. (2017) verified that firms should focus on the performance factors for building a successful CRM in order to have a strong connection with the consumers, which enhances the attitude toward customer retention. According to Lam et al. (2013), when an efficient electronic-based CRM strategy is implemented through customer focus, awareness of the quality of the relationship between the firm and its customers may be improved. Every bank's performance, according to Kebede and Tegegne (2018), is dependent on innovative CRM technology.

From the review of literature, customers' retention is linked to CRM practices through customer satisfaction. This is confirmed by Rizan et al. (2014) through their research, which discovered that customer loyalty and satisfaction had a substantial impact on the relationship between CRM practices and customer retention. Also, Customer satisfaction has a positive mediation effect on the link between CRM and customer loyalty, according to research by Long et al. (2013) and Panjaitan and Laely (2017). This paper thus examines CRM Practices, customer satisfaction and customer retention on clients at Ghana Commercial Bank (GCB), Tamale. Detailed information will be outlined to investigate the effect of CRM practices on customer retention and the mediating role of customer satisfaction between CRM practices and customer retention.

\section{Conceptual Framework}

The framework was developed in order to determine the most likely relationship between the dependent and independent variables. Customer retention was the dependent variable, while customer relationship management practices were the independent variable. Customer relationship practices were categorized as follows, namely customer focus, knowledge management, and technology-based CRM. CRM based on technology focuses on CRM system automation, functionality, user acceptability, and system integration (Foya et al., 2015). Customer knowledge, customer engagement, customer requirement, and customer feedback were all highlighted (Lohan, Lang \& Conboy, 2011). Knowledge management looked at the sharing of organizational knowledge and IT investment (Ali \& Alshawi, 2020). The conceptual framework was presented in figure 1.

Figure 1: Conceptual Framework on CRM practices, customer satisfaction and customer retention

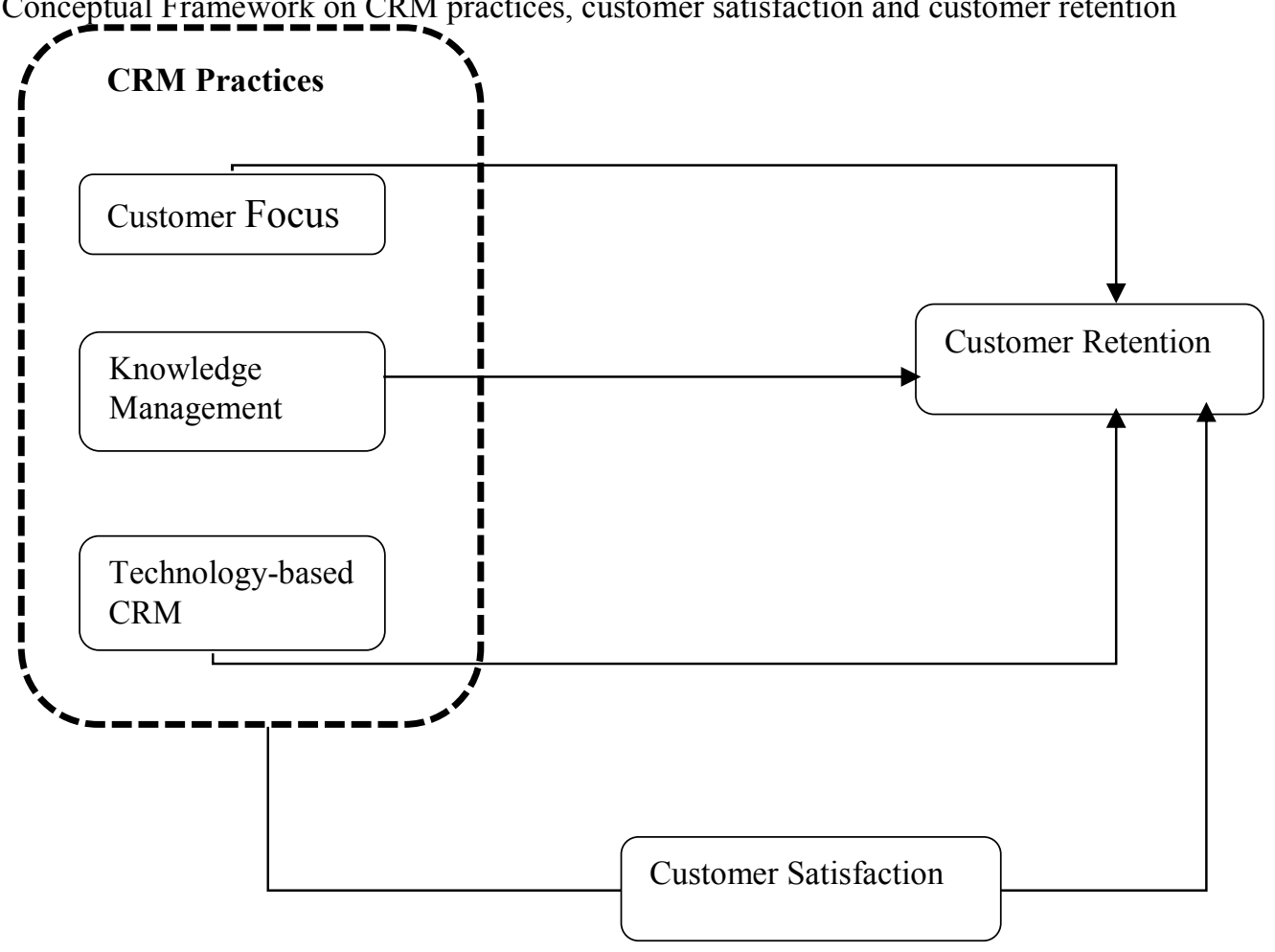

\section{Research Methodology}

The study adopted a quantitative and explanatory approach using self-administered questionnaires to collect information from the respondents. The study made use of this design because there was need to examine the relationship that exist among the variables of the study. Also, it was of necessity to generate deeper understanding on how the variables of the study relate. Further, the study adopted a quantitative approach. The quantitative approach surveys a large number of individuals and applies statistical techniques to recognize 
overall patterns in the relations of processes. The quantitative approach was adopted because the study made use of statistical techniques in drawing its analysis. In the context of this study, the population was customers at the Tamale GCB bank. The bank has 8,552 clients. The sample size for the study was 367 clients. The clients were deemed best for the study because they are the ones that patronizes the products and services of the bank. This was determined through the Krejcie and Morgan (1970) sample size determination table. The study employed the simple random sampling technique. This technique allows each individual to be chosen by chance and each member of the population has an equal chance of being included in the sample. Every possible sample of a given size has the same chance of been selected. The technique was chosen to avoid bias in the sampling. This study made use of a structured questionnaire. The question assumed a five (5) point Likert scale where 1 was least agreed and 5 was strongly agreed. There was need to code the responses from the questionnaire that were administered to the clients in order to be inputted into the right structure for analysis. The coded data was inputted into the SPSS (version 26) for processing. All missing values issues were dealt with to ensure the appropriateness of the data for meaningful analysis. The reliability of the measures of the instruments was checked using the Cronbach's Alpha. Measures with Cronbach's Alphas less than .7 were declared not reliable and measures with Cronbach's Alphas more than .7 were declared reliable. This coefficient measurement evaluates the scale's overall consistency (Cronbach, 1951). The result was presented in Table 1.

Table 1 Reliability co-efficient of Variables

\begin{tabular}{lcc}
\hline Questionnaire Items & No. of Items & Cronbach's Alpha \\
\hline Technology-based CRM & 5 & .874 \\
Knowledge Management & 4 & .741 \\
Customer Focus & 5 & .896 \\
Customer Retention & 5 & .892 \\
Customer Satisfaction & 5 & .710 \\
\hline
\end{tabular}

Source: Field Survey (2020)

The lowest and highest values for the variables examined are 0.710 and 0.896 , respectively. This means that all of the variables utilized in the research are valid and reliable. Regression analysis was then conducted to test the relationship between CRM practices and customer retention.

\section{Results/ Findings}

Demographic Characteristics of Respondents

Of the respondents who participated in the data collection, 182 out of the respondents (representing $48.6 \%$ ) were males and 185 of respondents (representing 50.4\%) were females. With a male - female ratio of 1:.98, gender bias was greatly reduced. The distribution of respondents is presented in Table 2.

Table 2 Demographics

\begin{tabular}{llcc}
\hline Demographic Variables & Categories & Frequencies & Percentages \\
\hline Gender & Male & 182 & 49.6 \\
\hline Total & Female & 182 & 50.4 \\
\hline Age & $18-28$ years & $\mathbf{3 6 7}$ & $\mathbf{1 0 0}$ \\
\hline & $29-39$ years & 61 & 16.6 \\
\hline & $40-50$ years & 111 & 34.1 \\
\hline & $51-61$ years & 125 & 10.9 \\
\hline Total & 62 years and above & 40 & 8.2 \\
\hline Education & & 30 & $\mathbf{1 0 0}$ \\
\hline & Certificate & $\mathbf{3 6 7}$ & 39.5 \\
\hline & HND & 145 & 30.8 \\
\hline & Bachelors & 113 & 16.6 \\
\hline Motal & Masters & 61 & 9.8 \\
\hline Years with the Bank & Others & 36 & 3.3 \\
\hline & $1-5$ years & 12 & $\mathbf{1 0 0}$ \\
\hline & $6-10$ years & $\mathbf{3 6 7}$ & 27.0 \\
\hline & $11-15$ years & 99 & 30.8 \\
\hline Total & $16-20$ years & 113 & 19.3 \\
\hline & $21-25 y e a r s$ & 71 & 9.0 \\
\hline & 26 years and above & 33 & 3.8 \\
\hline & & 14 & 10.1 \\
\hline
\end{tabular}




\section{Respondents' View on CRM Practices}

The results of the quantitative data of the five variables used in the study was investigated using mean statistics. With respect to customer focus, customers are of the view that the bank allows its staff to do whatever is in their best interests as seen in Table 3. This indicator's result was classified as "high" since it received a highest mean score of 4.15, which is between 3 and 5 on a Likert scale of 1 to 5 . Customers believe the bank offers avenues for continuous and one-on-one interaction with important customers when it comes to knowledge management (see Table 3). This indicator's result was classified as 'high' since it had a highest mean score of 4.46, which is in the range of 3 to 5 on a Likert scale. Clients believe that the bank has the appropriate software to serve its customers when it comes to technology-based CRM. This indicator's result was evaluated as "high" since it had a highest mean score of 4.21. In relation to customer satisfaction in Table 3, the customers trust the bank to provide the finest financial goods and services to him or her. This practice achieved a 'high' rating since it had a mean score of 4.42, which is between 3 and 5. In relation to customer retention in Table 3, customers feel empowered by individualized communications that promote positive bank interactions. This indicator achieved a 'high' rating since the mean score was 4.20, which is between 3 and 5 . All indicators under study achieved a mean score 3.91-4.46, this score falls between 3-5 on a Likert of 1-5, indicating positive agreement. This suggests that the majority of clients are totally satisfied with their banks' services and its management methods. Table 3 Descriptive Statistics of Variables

\begin{tabular}{|c|c|c|c|c|c|c|}
\hline Variables & & $\mathbf{N}$ & Lowest & Highest & Mean & $\begin{array}{c}\text { Std. } \\
\text { Deviation }\end{array}$ \\
\hline \multirow{7}{*}{$\begin{array}{l}\text { Customer } \\
\text { Focus }\end{array}$} & $\begin{array}{l}\text { The bank empowers its employees to do } \\
\text { whatever is in the best interest of customers }\end{array}$ & 367 & 1 & 5 & 4.15 & .997 \\
\hline & $\begin{array}{l}\text { The bank meets with customers to listen and } \\
\text { learn about their changing requirement }\end{array}$ & 367 & 1 & 5 & 4.12 & .957 \\
\hline & $\begin{array}{l}\text { The bank's actions and behaviors are always } \\
\text { consistent with their words regarding the } \\
\text { importance of customers }\end{array}$ & 367 & 1 & 5 & 3.98 & .895 \\
\hline & $\begin{array}{l}\text { Customer data and information are key to } \\
\text { policy and strategy formulation in the bank }\end{array}$ & 367 & 1 & 5 & 3.96 & .981 \\
\hline & $\begin{array}{l}\text { The bank meets with customers to discuss } \\
\text { performance issues and to strengthen their } \\
\text { relationship with the customers }\end{array}$ & 367 & 1 & 5 & 3.91 & .861 \\
\hline & $\begin{array}{l}\text { The bank empowers its employees to do } \\
\text { whatever is in the best interest of customers }\end{array}$ & 367 & 1 & 5 & 4.15 & .997 \\
\hline & $\begin{array}{l}\text { The bank meets with customers to listen and } \\
\text { learn about their changing requirement }\end{array}$ & 367 & 1 & 5 & 4.12 & .957 \\
\hline \multirow[t]{4}{*}{$\begin{array}{c}\text { Knowledge } \\
\text { Management }\end{array}$} & $\begin{array}{l}\text { The bank provides channels to enable } \\
\text { ongoing, two-way communication with key } \\
\text { customers and us }\end{array}$ & 367 & 1 & 5 & 4.46 & .696 \\
\hline & $\begin{array}{l}\text { Customers can expect prompt service from } \\
\text { employees of my organization }\end{array}$ & 367 & 1 & 5 & 4.45 & .831 \\
\hline & $\begin{array}{l}\text { The bank fully understands the needs of our } \\
\text { key customers via knowledge leaning }\end{array}$ & 367 & 1 & 5 & 4.13 & 1.043 \\
\hline & $\begin{array}{l}\text { The banks' employees are willing to help } \\
\text { customers in a responsive manner }\end{array}$ & 367 & 1 & 5 & 4.01 & .986 \\
\hline \multirow[t]{5}{*}{$\begin{array}{l}\text { Technology- } \\
\text { based CRM }\end{array}$} & $\begin{array}{l}\text { The bank has right software to service its } \\
\text { customers }\end{array}$ & 367 & 1 & 5 & 4.21 & .908 \\
\hline & $\begin{array}{l}\text { Individualized information about each } \\
\text { customer is available at all contact points }\end{array}$ & 367 & 1 & 5 & 4.20 & .908 \\
\hline & $\begin{array}{l}\text { The bank has right hardware to service its } \\
\text { customers }\end{array}$ & 367 & 1 & 5 & 4.08 & .863 \\
\hline & $\begin{array}{l}\text { The bank is able to consolidate all } \\
\text { information acquired about customers in } \\
\text { comprehensive, centralized, up-to-date } \\
\text { database }\end{array}$ & 367 & 1 & 5 & 4.05 & .895 \\
\hline & $\begin{array}{l}\text { The bank's information systems are } \\
\text { integrated across the different functional } \\
\text { areas }\end{array}$ & 367 & 1 & 5 & 4.03 & .943 \\
\hline
\end{tabular}




\begin{tabular}{|c|c|c|c|c|c|c|}
\hline Variables & & $\mathbf{N}$ & Lowest & Highest & Mean & $\begin{array}{c}\text { Std. } \\
\text { Deviation }\end{array}$ \\
\hline \multirow[t]{13}{*}{$\begin{array}{c}\text { Customer } \\
\text { Satisfaction }\end{array}$} & $\begin{array}{l}\text { I trust my bank to provide me with the best } \\
\text { financial products and services }\end{array}$ & 367 & 1 & 5 & 4.42 & .764 \\
\hline & $\begin{array}{l}\text { A complaint lodged by me is promptly } \\
\text { attended and the problem was resolved as } \\
\text { soon as possible }\end{array}$ & 367 & 1 & 5 & 4.38 & .797 \\
\hline & Bank charges for different services are fair & 367 & 1 & 5 & 4.30 & .785 \\
\hline & I am satisfied with the service quality & 367 & 1 & 5 & 4.26 & .801 \\
\hline & $\begin{array}{l}\text { I am satisfied with overall interaction with } \\
\text { the staff }\end{array}$ & 367 & 1 & 5 & 4.23 & .879 \\
\hline & $\begin{array}{l}\text { There is proper space for sitting, waiting, } \\
\text { writing and parking }\end{array}$ & 367 & 1 & 5 & 4.22 & .831 \\
\hline & $\begin{array}{l}\text { I am satisfied with the features and benefits } \\
\text { of the services of bank }\end{array}$ & 367 & 1 & 5 & 4.20 & .839 \\
\hline & $\begin{array}{l}\text { I prefer this bank because of transparency } \& \\
\text { reliability in financial transactions and in } \\
\text { other services }\end{array}$ & 367 & 1 & 5 & 4.16 & .850 \\
\hline & $\begin{array}{l}\text { The bank maintains personal relationship } \\
\text { with the customer }\end{array}$ & 367 & 1 & 5 & 4.15 & .920 \\
\hline & Bank is located at a convenient place & 367 & 1 & 5 & 4.14 & .828 \\
\hline & I use bank services quite often & 367 & 1 & 5 & 4.06 & .844 \\
\hline & $\begin{array}{l}\text { Periodic feedback review is sought after } \\
\text { raising complaint }\end{array}$ & 367 & 1 & 5 & 3.99 & .929 \\
\hline & $\begin{array}{l}\text { Complaints are welcomed and individual } \\
\text { attention is given to every customer } \\
\text { complaint }\end{array}$ & 367 & 1 & 5 & 3.94 & .880 \\
\hline \multirow[t]{10}{*}{$\begin{array}{l}\text { Customer } \\
\text { Retention }\end{array}$} & $\begin{array}{l}\text { I feel empowered through personalized } \\
\text { messages which encourage healthy relations } \\
\text { with my bank }\end{array}$ & 367 & 1 & 5 & 4.20 & .986 \\
\hline & $\begin{array}{l}\text { The bank frequently organizes customer } \\
\text { meets }\end{array}$ & 367 & 1 & 5 & 4.17 & .950 \\
\hline & $\begin{array}{l}\text { The bank retains its customers by its } \\
\text { branding strategies }\end{array}$ & 367 & 1 & 5 & 4.16 & .985 \\
\hline & $\begin{array}{l}\text { The bank provides timely responses to its } \\
\text { customer complaints }\end{array}$ & 367 & 1 & 5 & 4.12 & .960 \\
\hline & $\begin{array}{l}\text { The feedback is taken from customers on } \\
\text { regularly (weekly) basis }\end{array}$ & 367 & 1 & 5 & 4.02 & .893 \\
\hline & $\begin{array}{l}\text { The bank retains its customers by building } \\
\text { customer relationships }\end{array}$ & 367 & 1 & 5 & 3.99 & .895 \\
\hline & $\begin{array}{l}\text { The bank provides reliable services to its } \\
\text { customers }\end{array}$ & 367 & 1 & 5 & 3.97 & .988 \\
\hline & $\begin{array}{l}\text { Bank has a culture where customer is given } \\
\text { first preference }\end{array}$ & 367 & 1 & 5 & 3.95 & .988 \\
\hline & $\begin{array}{l}\text { The bank provides unique product to retain } \\
\text { its customers }\end{array}$ & 367 & 1 & 5 & 3.92 & .858 \\
\hline & $\begin{array}{l}\text { The bank provides quality services to its } \\
\text { customers }\end{array}$ & 367 & 1 & 5 & 3.91 & .867 \\
\hline
\end{tabular}

\section{Effect of CRM Practices on Customer Retention}

With respect to the first objective of the study multiple regression analysis was performed. Using the hierarchical multiple regression analysis, a diagnostic test was, first, conducted to check for multi co- linearity among the independent variables. This was used to examine the possible undesirable situation where the correlations among the variables are strong. The PASW Version 21.0 was used to assess the Variance Inflation Factor (VIF) that measures multicollinearity in the regression model, since multicollinearity misleadingly inflates the standard errors, thereby making some variables statistically insignificant, while they should otherwise be significant.

The VIF was used to measure how much the variance of the estimated coefficients increased over the case 
of no correlation among the independent variables. All the VIF values for the independent variables were within the acceptable threshold. This shows that none of the values was greater than five (5), which means that there was no collinearity associated with the variables. The VIF values were also inversely related to the Tolerance values (VIF $=1 /$ Tolerance). According to Sarstedt and Mooi (2019), large VIF values (a usual threshold is 10.0, which corresponds to a tolerance of 0.10 ) indicate a high degree of multicollinearity among the independent variables. In addition, under the collinearity diagnostics, condition index values of all the entered variables were less than 15 , indicating that there was no problem.

The ANOVA and model summary in Table 4 indicates a sig. value of 0.000 . The model summary also indicates an $\mathrm{R}$ square value of 0.753 . The sig. value of 0.000 indicates that statistically there is a strong significant relationship between CRM practices and customer retention. The R square value of 0.753 indicates that 75.30 per cent of variations in customer retention is explained by CRM practices.

Table 4Multiple Regression Analysis (ANOVA and model summary) on the effect of CRM practices on Customer Retention

\begin{tabular}{|c|c|c|c|c|c|}
\hline & Sum of Squares & $\overline{d f}$ & Mean Square & $\bar{F}$ & Sig. \\
\hline Regression & 122.805 & 3 & 40.935 & 368.149 & $.000^{\mathrm{b}}$ \\
\hline Residual & 40.362 & 363 & .111 & & \\
\hline Total & 163.167 & 366 & & & \\
\hline Model & $\begin{array}{c}\mathrm{R} \\
.868^{\mathrm{a}}\end{array}$ & $\begin{array}{c}\text { R Square } \\
.753\end{array}$ & $\begin{array}{c}\text { Adjusted R Square } \\
.751\end{array}$ & $\begin{array}{c}\text { Std. Error of the Estimate } \\
\qquad .33345\end{array}$ & \\
\hline
\end{tabular}

a. Dependent Variable: Customer Retention

b. Predictors: (Constant), Customer Focus, Knowledge Management, Technology-Based CRM

Table 5 illustrates the distinct contributions of the various CRM elements to retention. It shows that customer retention is influenced by variables such as technology, knowledge management, and customer focus. The most crucial element is customer focus, Knowledge management, and technology-based CRM in that sequence. All the CRM practices have their $p$-values as less than $0.05(\mathrm{p}<0.05)$ indicating a very significant effect on customer retention.

Table 5 Coefficient of CRM practices of customer retention

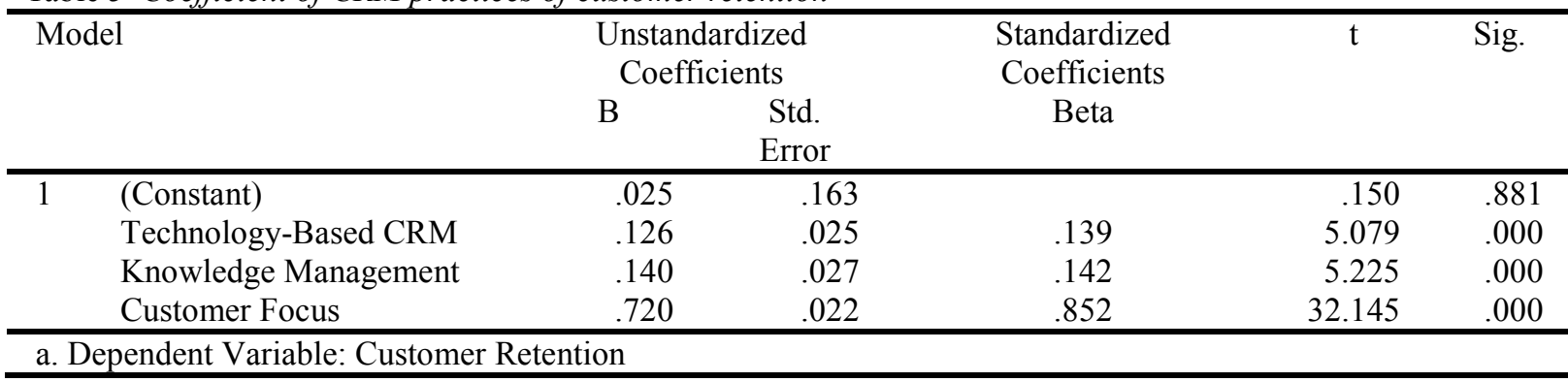

Mediating effect of customer satisfaction in the relationship between CRM Practices and Customer Satisfaction

With regards to the second objective to assess the mediating effect of customer satisfaction on the relationship between CRM practices (independent variable) and customers' satisfaction (mediating variable) were regressed against Customer Retention (dependent variable). The study revealed a positive path coefficient between CRM practices and customer satisfaction as dependent variable in Table 6 . This suggests a significant linkage between CRM practices and customer satisfaction. Also, the relationship between CRM practices and customer retention with customer satisfaction being a mediating variable was found to be significant as the p-value was less than 0.05 . 
Table 6 Coefficient of the Mediating Effect of CRM practices and Customer Satisfaction Variables on Customer Retention

\begin{tabular}{cccccc}
\hline $\mathrm{R}^{2}=.049 \mathrm{~F}(1,367)=18.914 \rho=0.000^{\mathrm{b}}$ & & & & \\
\hline & $\mathrm{B}$ & Std. Error & Beta & $\mathrm{t}$ & Sig. \\
(Constant) & 3.745 & .104 & & 36.048 & .000 \\
CRM Practices & .110 & .025 & .222 & 4.349 & .000 \\
Dependent Variable: Customer Satisfaction & & & & \\
\hline $\mathrm{R}^{2}=.451$ F (2, 364) $=149.38 \rho=0.000^{\mathrm{b}}$ & & & -3.858 & .000 \\
(Constant) & -1.449 & .376 & .647 & 16.642 & .000 \\
CRM Practices & .974 & .059 & .205 & 5.272 & .000 \\
Customer & .349 & .066 & & & \\
Satisfaction & & & & & \\
Total Effect & & & & & \\
\hline
\end{tabular}

Dependent Variable: Customer Retention

Further, the finding in Table 6 also revealed a positive path coefficient between CRM practices and customer satisfaction. Therefore, a regression (prediction) equation on the model above was adopted and formulated in line with the analysis model of Baron and Kenny (1986) and presented as follows; If Customer Retention $=\mathrm{CR}, \mathrm{CRM}=\mathrm{CRM}$ practices, Customer Focus $=\mathrm{X} 1$, Technology-based $\mathrm{CRM}=\mathrm{X} 2$, Knowledge Management $=\mathrm{X} 3$, and Error term $=\varepsilon$, then

$$
\begin{gathered}
\mathrm{CR}=A_{0}+\beta_{1} C R M+\beta_{2} C S+\varepsilon \text { where }(\mathrm{CRM}=\mathrm{BX} 1+\mathrm{BX} 2+\mathrm{BX} 3) \\
=-1.449+.974(\mathrm{CRM})+.349(\mathrm{CS})+\varepsilon
\end{gathered}
$$

If the test values for customer focus, knowledge management and technology -based CRM are ascertained, this model can be used to establish customer retention in the future.

\section{Discussion}

The first objective of the study was to assess the effect of CRM practices (such as customer focus, knowledge management and technology-based CRM) at GCB on customer retention. The results of the quantitative data of the different variables used in the study was firstly investigated using mean statistics. All indicators under study achieved a mean score 3.91-4.46, this score falls between 3-5 on a Likert of 1-5, indicating positive agreement between variables. This suggests that the majority of clients are totally satisfied with their banks' services and its CRM practices. In order to ascertain the reliability of the variables under study, a reliability test was performed using Cronbach's Alpha. The finding from the test revealed all variables been investigated were in between the lowest and highest values of 0.710 and 0.896 , respectively. This indicated all the variables under study were strongly reliable. Additionally, the findings from the Regression analysis (ANOVA and model) summary was presented in Table 3 . The model summary findings presented on the $\mathrm{R}, \mathrm{R}$ square, adjusted $\mathrm{R}$ square and the standard error in Table 3 . The $\mathrm{R}$ value revealed a strong relationship $\left(.868^{\mathrm{a}}\right)$ between the CRM practices and customer retention. The $\mathrm{R}$ square represents the coefficient of determination. The value of the $\mathrm{R}$ square (.753) communicates a strong relationship between the CRM practices and customer retention. This implies that $75.3 \%$ variation in the customer retention is explained by the CRM practices. This indicates that there is a significant relationship between CRM practices and customer retention. This revelation from the study is consistent with several studies, such as San and Hardjono (2017), Abbas et al. (2017), Bashir (2017), Hettiarachchy and Samarasinghe (2016), and Ramaj (2015), which also found that CRM and its practices had a positive and a significant impact on customer retention. This further suggests that banks' attempts to improve their CRM practices will help them retain customers. Moreover, the ANOVA results in Table 3 revealed the test significance for R and R square using the F-statistics. The F-statistics is computed by dividing the regression mean square by the residual mean square. The ANOVA results, showed a F-statistics significance value that is less than 0.01, meaning the CRM practices does well in explaining customer retention. The regression coefficient for each of the CRM practices were captured in Table 4. The results include the standardized and unstandardized beta coefficients, standard errors and the significance level. Under the unstandardized coefficient beta column, we have the constant value of .025 which stands for the gradient/slope/intercept in the regression equation.

With respect to technology-based CRM, the beta coefficient was .126 which stands for a positive influence on customer retention. This suggest that a percentage change in technology-based CRM will result in $12.6 \%$ changes in customer retention. This relationship was significant since it has a $\rho<.001$. This suggest that technology-based CRM has a positive significant influence on customer retention. It was pointed that technology-based CRM helps companies focus on internet-based customer service links to the right customers so as to attain customer retention. The finding is consistent with other studies such Radaideh and Al-Talafih (2017) and Lam et.al. (2013) which indicated that the use of various Electronic-CRM technologies in banks helps to 
retain customers

With respect to knowledge management, the beta coefficient was .140 which stands for a positive influence on customer retention. This suggest that a percentage change in knowledge management will result in a $14.0 \%$ change in customer retention. This relationship was significant since it has a $\rho<.001$. This suggest that knowledge management has a positive significant influence on customer retention. Knowledge is viewed as one of the important and high valued organization assets for customer retention (Chua and Banerjee, 2013). The findings from the study corroborates with that of Wang et. al., (2010) and Duwailah and Hashem (2019), which examined the impact of knowledge management on CRM approaches. This indicates strongly that knowledge management has a significant impact on customer loyalty, retention and satisfaction (Wang et al., 2010). Lastly, customer focus had a beta coefficient of .720 which stands for a positive influence on customer retention. This suggest that a percentage change in customer focus will result in a $72.0 \%$ change in customer retention. This relationship was significant since it has a $\rho<.001$. This suggest that customer focus has a positive significant influence on customer retention. Customer focus has been described as an employee's personal focus to provide excellent service to customers in order to retain them. An important condition that enables the organization to be truly customer-focused is the way in which it delivers value to its customers. As a prerequisite to organizational growth and success of its client base, customer engagements and interactions focus on managing the relationship between the organization and its present and future loyal customer base (Gebert et al., 2002). The findings support a previous study by So (2013) who discovered in his study that, customer involvement or interaction has a positive influence on loyalty and retention of brands. Consequently, the overall findings elucidated in this section also corroborates with a study of Martey (2014) which indicates that, when CRM is practiced successfully, organizations are able to meet customer expectations which automatically affect individuals ${ }^{\text {ee }}$ perspective in order to meet their expectations and retain them, promote customer retention. This indicates that CRM practices implemented effectively are intended to bring customer satisfaction and retention in service industries, thereby reflecting the business's revenue.

The second objective of the study was to examine the mediating effect of customer satisfaction in the relationship between CRM Practices and Customer Retention.

CRM practices (independent variable) and customers' satisfaction (mediating variable) were regressed against Customer Retention (dependent variable). The study revealed a positive path coefficient between CRM practices and customer satisfaction as dependent variable $(\beta=0.222$, $\mathrm{t}$ value $=4.349, \mathrm{p}$-value $=0.000)$. The findings suggest a significant linkage between CRM practices and customer satisfaction. Also, the relationship between CRM practices and customer retention with customer satisfaction being a mediating variable was found to be significant $(\beta=0455, p$-value $=0.000)$ as the $p$-value was less than 0.05 . Therefore, the finding revealed there is a significant mediating effect of customer satisfaction in the relationship between CRM practices and customer retention. Customer satisfaction being a dependent variable and CRM practices as the independent variable, the beta coefficient was .222 , which suggest a positive influence of CRM practices on customer satisfaction. It was also established that customer satisfaction has a positive path coefficient with customer retention. Customer satisfaction being a mediating variable, brought about a total effect of .0455 in Table 5. This confirms further that customer satisfaction mediates in the relationship between CRM practices and Customer retention. This is in tandem with previous studies of Long et al. (2013) and Panjaitan and Laely (2017), which also established that customer satisfaction has a positive mediation effect on the relationship between CRM practices and customer retention.

\section{Conclusions}

The revelations from the study, determined that CRM practices are vital in the Ghanaian banking industry in terms of strengthening long-term relationships with customers while also increasing business efficiency. The study revealed that CRM practices (customer focus, knowledge management and technology-based CRM) has a significant effect on customer retention. Further, the study also revealed that customer satisfaction mediates the relationship between CRM practices and customer retention in the banking industry. This means that Ghanaian banks who fail to properly integrate CRM into their operations will struggle to retain their loyal customers. Customer satisfaction, per the study and literature, has a significant impact on customer retention. In light of this, banks that want to keep their loyal customers must develop customer satisfaction approaches, since customer satisfaction leads to retention. The findings from the study reveal that there is a strong correlation between CRM practices and customer retention, with the role of customer satisfaction as a mediating effect between them. The findings also reveal significant implications for the banking sector in Ghana in achieving customer satisfaction and customer retention. Firstly, to accomplish customer satisfaction, it is very critical for Managers in banks to integrate and adopt the use of cutting-edge technology, innovative and unique products in their service delivery to customers. This will ensure quick-service time in bank services, thereby reducing the waiting period of customers and enhancing customer satisfaction, which is a mediating factor to customer retention. Moreover, to 
better serve their clients and establish a strong connection with them, Managers must educate and equip their staff with the most up-to-date skills and information.

Essentially, Managers should give their employees effective training on the significance of customer interactions (or engagements) and its influence on Customer Relationship Management practices and the retention of customers. Managers should also take a keen look at customer focus. From the findings, it was found to play a significant role in customer satisfaction and customer retention. Further, for staff of banks to build and sustain a healthy relationship with their clients, efforts must be made to know the types of customers they are dealing with, the demands and preferences of the customers. Consequently, Managers together with staff must meet with customers to address issues and to enhance their customer relationships. In addition, this will enable banks to ascertain first-hand information about their customer base in the formulation of strategic customerdefined retention policies.

\section{Delimitations and Future Research}

The study was delimited to variables such as CRM practices (technology-based CRM, customer focus and knowledge management), customer satisfaction and customer retention. This research was carried out in Ghana Commercial Bank, Tamale, and therefore may not be comparable to other region and branches. As a result, more Ghana Commercial Banks branches in Ghana, as well as a comparative study between a private bank and a state bank, must be investigated. It is also suggested that, future research integrate additional important variables such as internal marketing, and organisational culture to establish which aspects really influence customer retention.

\section{References}

Abbas, Aqsa; Chachar, Ayaz Ahmed; Bilal, Adil. International Research Journal of Arts and Humanities; Jamshoro Vol. 45, Iss. 45, (2017): 261-274.

Al-Radaideh, Q. A., \& Al-Talafih, H. (2017). The Influence Of E-Crm Technologies On Customer Loyalty: The Mediating Role Of Retention. International Journal of Business Research and Information Technology, $4(1), 80+$. https://link.gale.com/apps/doc/A525839325/AONE?u=anon $\sim$ cf7d56b9\&sid=googleScholar\&xid=46a132 78

Amir, M., Yousof, H. H\& Asma, E. (2014). The effect of using customer relationship management system on customer loyalty case study: Ansar bank's branches in East Azarbaijan. Indian Journal of Scientific Research, 8(1), 98-106.

Anubav, A.M. 2010. Factors affecting customer satisfaction and their relative im-portance in the retail banking sector: An empirical study, IUP Journal of Management Research, 9 (3), pp.6-23

Bashir, N. (2017), Impact of Customer Relationship Management on Customer Retention: A Case of Private Banks of Sialkot, Punjab. International Journal of Science and Technology Research, 6(8), 293-302.

Beck, T., \& Demirguc-Kunt, A. (2009). Financial institutions and markets across countries and over time-data and analysis. The World Bank.

Berry, L. L. (1983). Relationship marketing. Emerging perspectives on services marketing, 66(3), 33-47.

Chua, A. \& Banerjee, S. (2013). Customer Knowledge Management via Social Media: The case of Starbucks. Journal of Knowledge Management, 17(2):237_249.

Cronbach, L.J. (1951). Coefficient alpha and the internal structure of tests. Psychometrika, 16, 297-334.

Daly, S., \& Frikha, M. (2016). Banks and economic growth in developing countries: What about Islamic banks? Cogent Economics \& Finance, 4 (1), 1-26.

Duwailah, A. F., \& Hashem, N. T. (2019). The impact of knowledge management on CRM approaches. Management and Organizational Studies, 6(1), 20-30.

Foya, A.H., Kilika, J.M., \& Muathe, S.M. (2015). Relating Technology Based CRM to Service Quality in the Telecommunications Industry in Arusha City, Tanzania. Science journal of business management, 3, 209.

Ganiyu, R.A. (2017), "Customer satisfaction and loyalty: A study of interrelationships and effects in Nigerian domestic airline industry", Oradea Journal of Business and Economics, Vol. 2 No. 1, pp. 7-20.

Gayathry, S. (2016). Customer relationship management model for banks. Journal of Internet Banking and Commerce, 21(S5), 1-12.

Gittell, J. H. (2002). Relationships between service providers and their impact on customers. Journal of Service Research, 4(4), 299-311.

Grönroos, C. (2004). The relationship marketing process: communication, interaction, dialogue, value. Journal of business \& industrial marketing, 19(2), 99-113.

Gupta, S., \& Lehmann, D. R. (2003). Customers as assets. Journal of interactive Marketing, 17(1), 9-24.

Hasanat, W. M., Hoqueb, A., \& Hamid, A. B. A. (2019). Effect of customer relationship management in digital marketing for customer satisfaction and loyalty. International Conference on Business, Accounting, Finance and Economics, University Tunku Abdul Rahman,Kampar, Perak, Malaysia. 
Hettiarachchy, B. S., \& Samarasinghe, D. S. R. (2016, December). Influence of Relationship Marketing on Customer Retention in Sri Lankan Banking Industry. In University of Sri Jayewardenepura, Sri Lanka, 13thInternational Conference on Business Management (ICBM).

Kebede, M. A., \& Tegegne, L. Z. (2018). The effect of customer relationship management on bank performance: In context of commercial banks in Amhara Region, Ethiopia. Cogent Business \& Management, 5, 1-9.

Kent, E. \& Löfmarck, V.A. 2000. Customer retention, purchasing behavior and relationship substance in professional services, Industrial Marketing Management, 29(4), pp.363-372.

Khadka, K., \& Maharjan, S. (2017). Customer satisfaction and customer loyalty. Centria University of Applied Sciences Pietarsaari.

Kotler, P. and Keller, K., 2016. Marketing management. 15th ed. Harlow: Pearson.

Krejcie, R. V., \& Morgan, D. W. (1970). Determining sample size for research activities. Educational and Psychological Measurement, 30(3), 607-610.

Lam, C. Y. A., Cheung, R., \& Lau, M. M. (2013). The influence of internet-based customer relationship management on customer loyalty. Contemporary Management Research, 9(4), 419-439.

Long, C. S., Khalafinezhad, R., Ismail, W. K. W., \& Rasid, S. Z. A. (2013). Impact of CRM factors on customer satisfaction and loyalty. Asian Social Science, 9(10), 247.

Mishra, U. S., at al. (2011). CRM in banks: a comparative study of public and private sectors in India. European Journal of Social Sciences, Vol.24, No. 2, 265-277

Molapo, M. E., \& Mukwada, G. (2011). The impact of customer retention strategies in the South African cellular industry: The case of the Eastern Free State. International Journal of Business, Humanities and Technology, 1(2), 52-60.

Narteh, B. and Kuada, J. (2014), "Customer satisfaction with retail banking services in Ghana", Thunderbird International Business Review, Vol. 56 No. 4, pp. 353-371.

Nunnally, J. C. (1978). Psychometric theory. New York: McGraw-Hill Inc.

Ogburu, E. E. \& Usman, A. (2012). Imperatives of customer relationship management in Nigerian banking industry, Kuwait Chapter of Arabian Journal of Business and Management Review, 2, (1), 59-72

Oogarah-Hanuman, V., Pudaruth, S., Kumar, V., \& Anandkumar, V. (2011). A study of customer perception of CRM initiatives in the Indian banking sector. Research journal of social science and management, 1(04).Oxford University Press.

Panjaitan, H., \& Laely, N. (2017). The role of relationship marketing, and satisfaction as variable mediation: Study at Bank BPR UMKM East Java in Surabaya, International Review of Management and Marketing, 7(5), 105-112.

Parvatiyar, A., \& Sheth, J. N. (2001). Customer relationship management: Emerging practice, process, and discipline. Journal of Economic \& Social Research, 3(2).

Peltier, J. W., Schibrowsky, J. A., \& Zhao, Y. (2009). Understanding the antecedents to the adoption of CRM technology by small retailers: Entrepreneurs vs owner-managers. International Small Business Journal, 27(3), 307-336.

Pleshko, L.P. and Heiens, R.A. (2015), "Customer satisfaction and loyalty in the Kuwaiti retail services market: why are satisfied buyers not always loyal buyers?", The International Review of Retail, Distribution and Consumer Research, Vol. 25 No. 1, pp. 55-71.

Ramaj, A. C. (2015). Customer relationship management (CRM) in banking sector in Albania. European Journal of Economics and Business Studies, 1(2), 136-143.

Reichheld, F. F., \& Covey, S. R. (2006). The ultimate question: Driving good profits and true growth (p. 28). Boston, MA: Harvard Business School Press.

Rizan, M., Warokka, A., \& Listyawati, D. (2014). Relationship marketing and customer loyalty: Do customer satisfaction and customer trust really serve as intervening variables? Journal of Marketing Research and Case Studies,

Rouholamini, M., \& Venkatesh, S. (2011). A study of customer relationship management Iranian banking industry. International Journal of Information Technology and Knowledge Management, 4(2), 723-729.

Saksonova, S., \& Koleda, O. (2017). Evaluating the Interrelationship between Actions of Latvian Commercial Banks and Latvian Economic Growth. Procedia Engineering, 178 (1), 123-130.

San, P. L., \& Hardjono, B. (2017). Customer relationship management implementation and its implication to customer loyalty in hospitality industry. Jurnal Dinamika Manajemen, 8(1), 92-107.

So, K. F. K. (2013). An investigation of the role of customer engagement in strengthening service brand loyalty. Ph.D Thesis, Griffith Business School, Griffith University.

Tauni, S., Khan, R., Durrani, M. K., \& Aslam, S. (2014). Impact of customer relationship management on customer retention in the telecom industry of Pakistan. Industrial Engineering Letters, 4(10), 54-59.

Tseng, S. M. (2016). Knowledge management capability, customer relationship management, and service 
quality. Journal of enterprise information management, 29(2), 202-221.

Tursoy, T. (2018). Risk management process in banking industry. 10.13140/RG.2.2.14737.74085.

Tweneboah-Koduah, E. and Farley, Y.D. (2015), "Relationship between customer satisfaction and customer loyalty in the retail banking sector of Ghana", International Journal of Business and Management, Vol. 11 No. 1, pp. 249-262. 